Article

\title{
Presence of Antibiotic-Resistant Escherichia coli in Wastewater Treatment Plant Effluents Utilized as Water Reuse for Irrigation
}

\author{
Asli Aslan *, Zachariah Cole, Anunay Bhattacharya ${ }^{(D)}$ and Oghenekpaobor Oyibo \\ Department of Epidemiology and Environmental Health Sciences, Georgia Southern University, \\ Statesboro, GA 30460, USA; zc00856@georgiasouthern.edu (Z.C.); ab10694@georgiasouthern.edu (A.B.); \\ oo00806@georgiasouthern.edu (O.O.) \\ * Correspondence: aaslan@georgiasouthern.edu; Tel.: +1-912-478-2565
}

Received: 20 May 2018; Accepted: 15 June 2018; Published: 18 June 2018

\begin{abstract}
Providing safe water through water reuse is becoming a global necessity. One concern with water reuse is the introduction of unregulated contaminants to the environment that cannot be easily removed by conventional wastewater treatment plants (WWTP). The occurrence of ampicillin, sulfamethoxazole, ciprofloxacin, and tetracycline-resistant Escherichia coli through the treatment stages of a WWTP (raw sewage, post-secondary, post-UV and post-chlorination) was investigated from January to May 2016. The highest concentrations of antibiotic resistant E. coli in the effluent were detected in April after rainfall. Ampicillin-resistant E. coli was the most common at the post UV and chlorination stages comprising $63 \%$ of the total E. coli population. The minimum inhibitory concentration (MIC) analysis showed that one in five isolates was resistant to three or more antibiotics, and the majority of these E. coli were resistant to ampicillin, followed by sulfamethoxazole and ciprofloxacin. The highest MIC was detected at the finished water after application of multiple disinfection methods. Tetracycline resistance was the least observed among others, indicating that certain drug families may respond to wastewater treatment differently. Currently, there are no policies to enforce the monitoring of antibiotic-resistant pathogen removal in WWTP. Better guidelines are needed to better regulate reuse water and prevent health risk upon exposure to antibiotic-resistant bacteria.
\end{abstract}

Keywords: antibiotic resistance; chlorination; Escherichia coli; fecal indicator bacteria; reuse water; UV-disinfection

\section{Introduction}

The discovery of antibiotics has been one of the significant successes in human history. Most of these pharmaceuticals, however, become irrelevant to the disease they were intended to treat over time, as microorganisms have rapidly developed resistance mechanisms to fight back this once lifesaving intervention. Today, over 20,000 potential resistance genes in genome sequencing databases have been discovered since the first antibiotic resistance reported in the late 1930s, right after its medicinal use [1].

Microorganisms harboring resistance genes end up in water [2] and soil [3]. Wastewater [4], agricultural runoff [5], and hospital waste [6] have been reported as sources of antibiotic resistance in the aquatic environment. Water contaminated with antibiotic-resistant bacteria (ARB) has the potential to affect aquatic biodiversity [7,8] and human health adversely. These organisms are introduced to our drinking water resources $[9,10]$ and food systems through irrigation $[11,12]$. This issue has become a global concern, and the World Health Organization has recently declared ARB as an emerging pollutant in water [13]. 
It is necessary to address problems arising from water reuse due to water scarcity issues worldwide. One potential concern with reuse is that chemical and biological contaminants in the WWTP effluents can be introduced to the environment. In an earlier study, [14] detected several pharmaceutical and personal care products in surface water and water $30 \mathrm{~cm}$ beneath the soil where turf-grass fields were irrigated with reuse water. Today, with increasing water scarcity, WWTP in some states such as California, Texas, and Arizona have been using reclaimed water for irrigation purposes. According to the USEPA, in 2012, 30 states and one U.S. territory have adopted water reuse regulations [15]. Recycled water has been monitored by targeting fecal coliform bacteria [16], but antibiotic-resistant indicator bacteria have not been a part of the monitoring efforts.

The purpose of this study was to determine the antibiotic removal efficacy of a conventional WWTP whose effluents were utilized to irrigate recreational landscapes. Escherichia coli, as the fecal indicator bacteria, were targeted for antibiotic resistance in the WWTP. Ampicillin, sulfamethoxazole, ciprofloxacin and tetracycline-resistant $E$. coli were cultured to calculate the removal rates and variability in the resistant population from inflow to the effluent (reuse water). Furthermore, the impact of multiple disinfection steps on the removal of these E. coli populations was compared to provide a more detailed assessment of antibiotic resistance in reuse water.

\section{Materials and Methods}

\subsection{Sample Collection}

A WWTP serving a small urban community with a population of 25,000 people in Georgia was used for the study. The plant did not receive any industrial discharge. Samples were collected during morning hours (before $9 \mathrm{am}$ ), and sampling was repeated five times in 2016 (January-May). Triplicates of grab samples $(1 \mathrm{~L})$ were collected from the inflow, post-secondary, post-UV, and post-chlorination stages. All samples $(n=60)$ were transported to the laboratory on ice and processed within $6 \mathrm{~h}$ of collection. Seven days' cumulative precipitation data (total precipitation of the day of sampling and previous six days) were obtained from the University of Georgia Weather Network (www.georgiaweather.net).

\subsection{Antibiotic Resistant Escherichia coli Culture Collection}

\subsubsection{Escherichia coli Isolation}

Serial dilutions from $10^{1}$ to $10^{6}$ were prepared for the influent and secondary effluent by using sterile phosphate saline water. Triplicates of diluted influent, secondary effluent, undiluted UV-treated effluent, and chlorinated reclaimed water were filtered through a sterile membrane filtration system using $0.45 \mu \mathrm{m}$ sterile filters. The chlorinated samples were neutralized with $10 \%$ sodium thiosulfate prior to analysis. Presumptive Escherichia coli were grown on $\mathrm{mI}$ agar at $35 \pm 0.5^{\circ} \mathrm{C}$. for $18 \mathrm{~h}$ [15]. The $\mathrm{mI}$ medium contained cefsulodin (final concentration $5 \mu \mathrm{g} / \mathrm{mL}$ ) and has been reported to inhibit the growth of gram-positive organisms and non-coliform gram-negative bacteria in the literature $[15,16]$.

The antibiotics tested for resistance in E. coli were selected from among the most commonly used and clinically relevant pharmaceuticals (Table 1). Antibiotic-resistant presumptive E. coli were enumerated by culturing a separate set of filters on $\mathrm{mI}$ Agar plates with an antibiotic of concern-tetracycline (final concentration $16 \mu \mathrm{g} / \mathrm{L}$ ), ampicillin (final concentration $32 \mu \mathrm{g} / \mathrm{L}$ ), sulfamethoxazole (final concentration $350 \mu \mathrm{g} / \mathrm{L}$ ) and ciprofloxacin (final concentration $4 \mu \mathrm{g} / \mathrm{L}$ ) - at $37 \pm 0.5^{\circ} \mathrm{C}$. All antibiotic concentrations were based on the Clinical \& Laboratory Standards Institute (CLSI, Wayne, PA, USA) breakpoints [17]. A control set of filters were also incubated on media without antibiotics at the same conditions, and antibiotic resistance was calculated as percentages by using the formula [18]:

$$
\% \text { intermediate or resistant }=\frac{(\text { Presumptive E. coli }) \text { on antibiotic plate }}{(\text { Presumptive E. coli) on control plate }} \times 100
$$


Table 1. Antibiotics used in the study.

\begin{tabular}{ccc}
\hline Antibiotic & Abbreviation & Drug Family \\
\hline Ampicillin & AM & $\beta$-lactam penicillin \\
Ciprofloxacin & CI & Fluoroquinolone \\
Sulfamethoxazole/Trimethoprim & ST & Folic acid synthesis inhibitor \\
Tetracycline & TC & Tetracycline \\
\hline
\end{tabular}

\subsubsection{Isolate Identification}

Colonies were randomly picked from the $\mathrm{mI}$ plates in aseptic conditions, transferred into typtic soy broth (TSB) and grown in a shaker incubator at $37 \pm 0.5^{\circ} \mathrm{C}$ for $18 \mathrm{~h}$. These cultures were then washed with phosphate saline solution three times and finally stored in cryovials containing TSB with $50 \%$ glycerol at $-80{ }^{\circ} \mathrm{C}$ for further analysis.

The species of these isolates were further confirmed by real time polymerase chain reaction. Briefly, cultures grown overnight were lysed in a bead mill for $60 \mathrm{~s}$ at $5000 \mathrm{rpm}$ and the debris was removed by centrifugation [19]. The DNA concentration at the end of the crude extraction was measured using a UV-spectrophotometer (NanoDrop ${ }^{\mathrm{TM}}$ 2000, Thermo Scientific, Wilmington, DE, USA). Each DNA extract was analyzed in duplicate by the EC23S857 assay for E. coli [20]. The reaction mixture contained $12.5 \mu \mathrm{l}$ of Environmental Master Mix 2.0, $2.5 \mu \mathrm{L}$ of $2 \mathrm{mg} / \mathrm{mL}$ bovine serum albumin, $1 \mu \mathrm{M}$ of each primer, $2 \mu \mathrm{L}$ of DNA-free water and $5 \mu \mathrm{L}$ of the DNA extracts for a total reaction volume of $25 \mu \mathrm{L}$; and the thermal cycling protocols were $10 \mathrm{~min}$ at $95^{\circ} \mathrm{C}$, followed by 40 cycles of $15 \mathrm{~s}$ at $95^{\circ} \mathrm{C}$ and $60 \mathrm{~s}$ at $56^{\circ} \mathrm{C}$. A positive control (E. coli, ATCC ${ }^{\circledR} 25922^{\mathrm{TM}}$ ) and a no template control were also run during the analysis for quality control.

\subsection{Antibiotic Susceptibility Testing of the Isolates}

The E. coli isolates $(n=96)$ were further tested for antibiotic susceptibility by Epsilometer test $\left(\right.$ ETEST $^{\circledR}$ ) (bioMérieux, Marcy l'Etoile, France) as described by the manufacturer. Briefly, overnight cultures of isolates were streaked on Mueller Hinton Agar plates and antibiotic strips were placed on these plates after they were completely dry. These plates were then inverted and placed in a $35 \pm 0.5^{\circ} \mathrm{C}$ incubator for $18 \mathrm{~h}$. Each isolate was tested for ampicillin, ciprofloxacin, sulfamethoxazole and tetracycline susceptibility. At the end of the incubation, the minimum inhibitory concentration (MIC) values for each isolate and each antibiotic were recorded as described by the manufacturer. The CLSI breakpoints were used to interpret the data [13] and were reported as susceptible (S), intermediate (I) or resistant (R).

\subsection{Data Analysis}

The data were imported and the analysis was performed using the SAS (Statistical Analysis Software) 9.4. Univariate analysis for each variable was performed to assess the normality and distribution. The difference between the mean of the different antibiotic resistant bacteria at different stages of wastewater treatment was assessed using the Wilcoxon rank sum test (NPAR1WAY).

\section{Results}

\subsection{Presumptive E. coli Growth on Plates Supplemented with Antibiotics}

\subsubsection{Growth on the Control Plates}

The presumptive E. coli entering the WWTP $\left(2.5 \times 10^{7} \pm 1.36 \times 10^{7} \mathrm{CFU} / 100 \mathrm{~mL}\right)$ were removed significantly during UV disinfection with an average $5.2 \log$ (Table 2), and an additional $1.1 \log$ reduction was achieved with chlorination before the treated effluent was released for irrigation purposes. Two out of five sampling events (February and April) had the highest number of 
the presumptive E. coli $\left(1.1 \times 10^{2}\right.$ and $3.2 \times 10^{2} \mathrm{CFU} / 100 \mathrm{~mL}$ respectively) (Figure 1$)$ at the disinfected effluent stage.

Table 2. Log removal of Escherichia coli in different treatment stages.

\begin{tabular}{ccccc}
\hline Media & Influent to Secondary & Secondary to UV & Influent to UV & Influent to UV + Chlorination \\
\hline Control & -2.68 & -2.56 & -5.24 & -6.33 \\
ST & -2.55 & -2.61 & -5.17 & -6.15 \\
CI & -3.11 & -2.17 & -5.29 & -5.95 \\
TC & -2.36 & -2.90 & -5.26 & -5.79 \\
AM & -2.50 & -2.83 & -5.33 & -6.26 \\
\hline
\end{tabular}
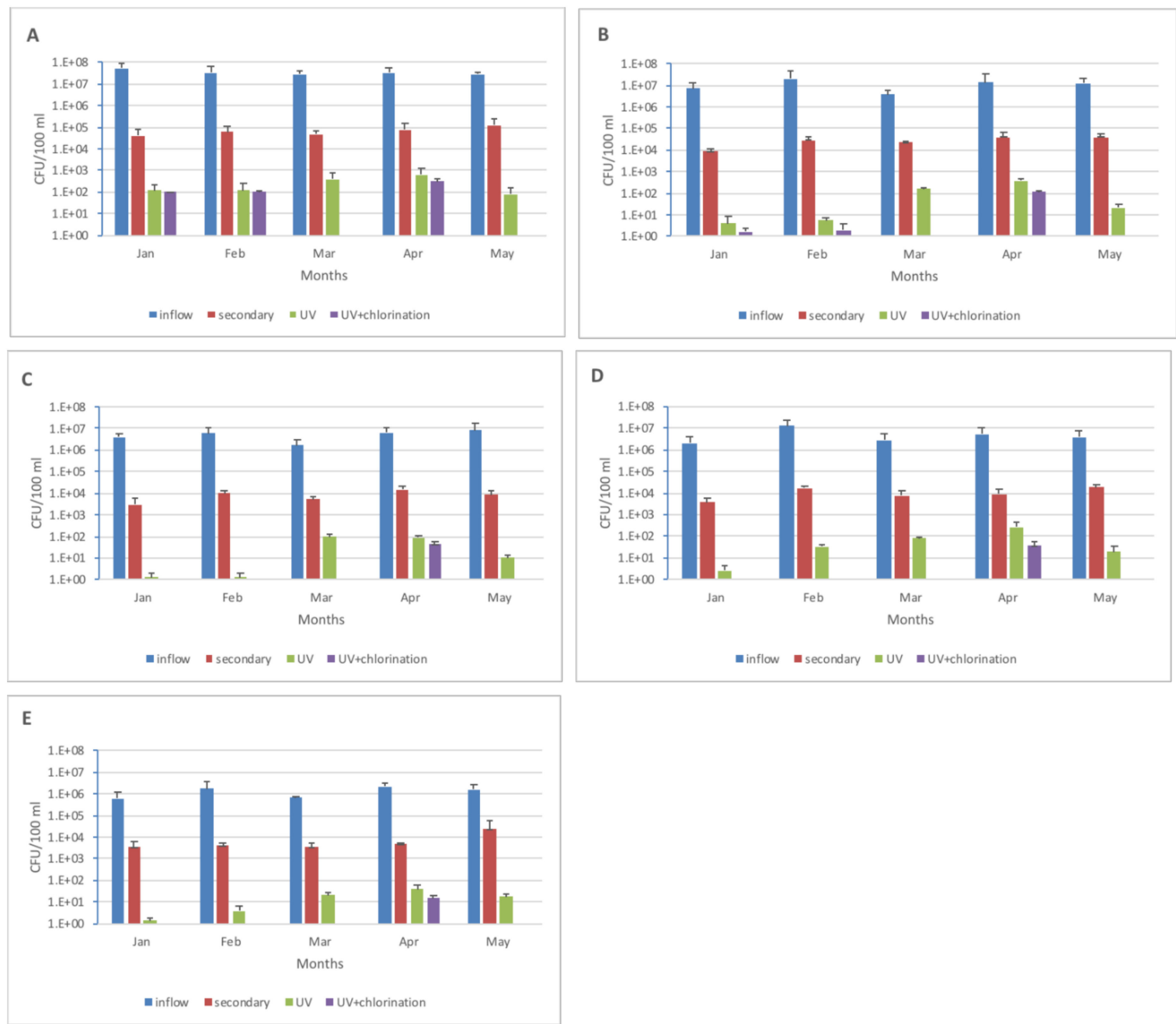

Figure 1. Escherichia coli growth on control (A), ampicillin (B), ciprofloxacin (C), sulfamethoxazole (D) and tetracycline (E) supplemented media.

\subsubsection{E. coli Growth on Antibiotic Supplemented Media}

The mean concentrations of ampicillin resistant E. coli that grew on AM/MI agar were higher than the E. coli detected on any other antibiotic supplemented media. The mean concentrations of E. coli were $1.2 \times 10^{7} \pm 1.04 \times 10^{7} \mathrm{CFU} / 100 \mathrm{~mL}$ at the inflow and decreased down to $2.4 \times 10^{1} \pm 5.1 \times 10^{1} \mathrm{CFU} / 100 \mathrm{~mL}$ at the reclaimed water stage. Almost half $(47 \%)$ of $E$. coli entering the WWTP were able to grow on the AM/MI agar (Table 3). An additional 0.9 logs of E. coli were removed with the chlorination after the conventional treatment and UV disinfection (Table 2). At the effluent, the percentage of the presumptive E. coli that were able to grow on the AM/MI agar 
increased significantly (Table 3). E. coli was detected post-chlorination in January, February and April $\left(2 \times 10^{0}, 4 \times 10^{0}\right.$ and $1.2 \times 10^{2} \mathrm{CFU} / 100 \mathrm{~mL}$ respectively) on this medium. April was also the month with the highest amount of precipitation (total of 1.5 inches in seven days prior to the sampling) followed by January and February (Figure 2).

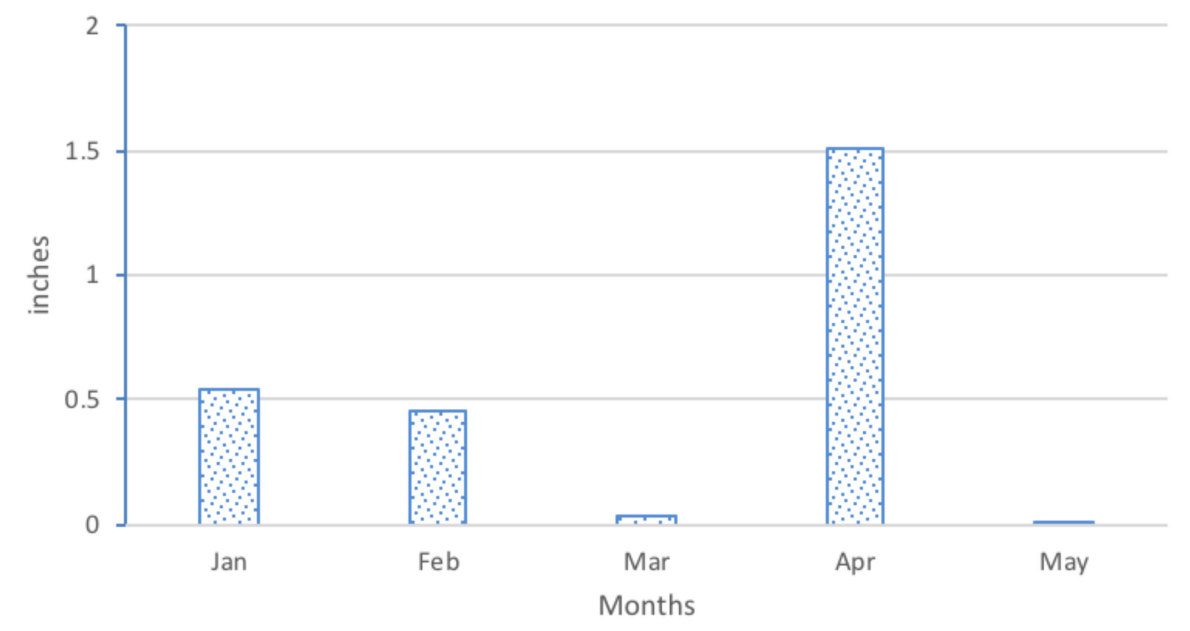

Figure 2. Cumulative precipitation (7 days total) before each sampling event.

Table 3. The percentage of E. coli growth on media supplemented with antibiotics through the treatment stages.

\begin{tabular}{ccccc}
\hline Stage & AM & ST & CI & TC \\
\hline Inflow & 47 & 24 & 19 & 6 \\
Secondary & 42 & 17 & 12 & 12 \\
UV & 47 & 29 & 16 & 5 \\
UV + chlorination & 63 & 21 & 25 & 9 \\
\hline
\end{tabular}

At the inflow, E. coli growth on sulfamethoxazole supplemented MI media (ST/MI) reached $6.1 \times 10^{6} \pm 6.95 \times 10^{6} \mathrm{CFU} / 100 \mathrm{~mL}$. These concentrations decreased to $7.2 \times 10^{1} \pm 1.07 \times 10^{2}$ CFU / $100 \mathrm{~mL}$ and $8 \times 10^{0} \pm 1.57 \times 10^{1} \mathrm{CFU} / 100 \mathrm{~mL}$ post UV and chlorination stages, respectively. Similar to the control and AM/MI, E. coli growth on ST/MI media was the highest in April $\left(2.6 \times 10^{2} \mathrm{CFU} / 100 \mathrm{~mL}\right)$.

E. coli concentrations on ciprofloxacin supplemented media (CI/MI agar) ranked third among other antibiotic conditions $\left(4.7 \times 10^{6} \pm 3.59 \times 10^{6} \mathrm{CFU} / 100 \mathrm{~mL}\right)$. Almost one fifth $(19 \%)$ of the presumptive E. coli population at the inflow could grow on CI/MI agar. The number of bacteria decreased to $9.6 \times 10^{0} \pm 1.92 \times 10^{1} \mathrm{CFU} / 100 \mathrm{~mL}$ post-chlorination, and $25 \%$ of the E. coli were able to grow on the $\mathrm{CI} / \mathrm{MI}$ agar at this last stage (Table 3 ).

E. coli growth on tetracycline supplemented media had the lowest occurrence at the inflow with a mean of $1.4 \times 10^{6} \pm 8.99 \times 10^{5} \mathrm{CFU} / 100 \mathrm{~mL}$ (Figure 1 ). Only $6 \%$ of the E. coli entering the WWTP grew on the TI/MI agar. However, the percentage of E. coli doubled post-secondary stage (12\%). Chlorination followed by UV disinfection removed some of these bacteria, and $9 \%$ of the E. coli were able to grow on the TC/MI agar at the end of the treatment process.

The nonparametric analysis using the Wilcoxon rank sum test yielded significant results for all the antibiotics. The difference between inflow and UV, inflow and UV + chlorination, and secondary and UV for ampicillin, ciprofloxacin, sulfamethoxazole, and tetracycline were strongly significant $(p<0.001)$. The difference was moderately significant for ampicillin, ciprofloxacin, and sulfamethoxazole between UV and chlorination $(p<0.05)$. Tetracycline concentrations, on the other hand, were not significant between these two disinfection stages $(p>0.05)$. 


\subsubsection{Antibiotic Susceptibility in E. coli Isolates}

All isolates were confirmed as E. coli based on PCR validation. The cycle thresholds for isolates ranged from 18 to 28. Antibiotic resistance was observed in E. coli isolates obtained from different stages of treatment (Table 4). The highest resistance was to ampicillin (85\% R and 1\% I). Among these isolates, sulfamethoxazole resistance ranked second (Table 4). Ciprofloxacin and tetracycline resistant E. coli were the least observed isolates (10\% R and $20 \%$ I for CI and 30\% R for TC, respectively).

Table 4. Percentage of antibiotic resistant E. coli isolates.

\begin{tabular}{|c|c|c|c|c|}
\hline \multirow[t]{2}{*}{ Antibiotic } & \multicolumn{3}{|c|}{ MIC Interpretive Criteria $(\mu \mathrm{g} / \mathrm{mL})$} & \multirow[t]{2}{*}{ Percent Resistant $^{\dagger}(n=96)$} \\
\hline & $\mathrm{S}$ & $\mathrm{I}$ & $\mathrm{R}$ & \\
\hline AM & $\leq 8$ & 16 & $\geq 32$ & 95 \\
\hline $\mathrm{CI}$ & $\leq 1$ & 2 & $\geq 4$ & 30 \\
\hline ST & $\leq 2$ & - & $\geq 4$ & 70 \\
\hline $\mathrm{TC}$ & $\leq 4$ & 8 & $\geq 16$ & 30 \\
\hline
\end{tabular}

Resistance to three or more antibiotics (multidrug-resistant) was observed in $21 \%$ of the E. coli isolates. Based on the minimum inhibitory concentrations, resistance to ampicillin was widespread among the multidrug resistant E. coli and four of these isolates had ampicillin MIC $>256 \mu \mathrm{g} / \mathrm{mL}$ (Table 5). Three of these high MICs (EC5, EC9 and EC14) were isolated from the effluent where both UV and chlorination was applied to the finished water. Two of these isolates were also resistant to tetracycline with MIC $>256 \mu \mathrm{g} / \mathrm{mL}$ (EC5 and EC9). Ampicillin, ciprofloxacin, and trimethoprim-sulfamethoxazole multidrug resistance was observed in 15 of the E. coli isolates $(75 \%)$. One isolate (EC12) was resistant to all four antibiotics.

Table 5. The minimum inhibitory concentration (MIC) values of multidrug-resistant E. coli.

\begin{tabular}{cccccc}
\hline Isolate & Location & AM & CI & ST & TC \\
\hline EC1 & inflow & 64 & 4 & 6 & 2 \\
EC2 & secondary & 64 & 2 & 4 & 3 \\
EC3 & secondary & 48 & 3 & $>32$ & 0.5 \\
EC4 & inflow & 48 & 8 & 6 & 0.38 \\
EC5 & UV + chlorination & $>256$ & 0.5 & $>32$ & $>256$ \\
EC6 & UV + chlorination & 48 & 2 & $>32$ & 2 \\
EC7 & UV + chlorination & 64 & 24 & $>32$ & 4 \\
EC8 & UV & 48 & 3 & 4 & 1 \\
EC9 & UV + chlorination & $>256$ & 3 & 0.047 & $>256$ \\
EC10 & UV + chlorination & 128 & 6 & 4 & 4 \\
EC11 & secondary & $>256$ & 3 & 4 & 4 \\
EC12 & UV & 64 & 2 & 12 & 15 \\
EC13 & inflow & 64 & 4 & 0.38 & 24 \\
EC14 & UV + chlorination & $>256$ & 6 & $>32$ & 3 \\
EC15 & inflow & 48 & $>32$ & $>32$ & 4 \\
EC16 & inflow & 16 & 0.016 & 4 & 32 \\
EC17 & inflow & 24 & 4 & 0.047 & $>256$ \\
EC18 & UV & 24 & 3 & 24 & 0.5 \\
EC19 & UV & 48 & 4 & 6 & 2 \\
EC20 & secondary & 48 & 3 & $>32$ & 2 \\
\hline
\end{tabular}

\section{Discussion}

In the study, the occurrence of antibiotic-resistant E. coli in a conventional WWTP in which effluents have been utilized to irrigate recreational landscapes was investigated. The results show 
that reclaimed water harbors E. coli resistant to a suite of commonly used antibiotics in medicine (ampicillin, sulfamethoxazole, ciprofloxacin, and tetracycline). The resistance to these antibiotics was also observed among E. coli isolates from irrigation waters in other studies [21-23]. Culturable fecal indicator bacteria such as E. coli have been instrumental in monitoring the impact of effluents on the environment [24]. According to the National Pollutant Discharge Elimination System (NPDES), a WWTP in the USA can only discharge effluents below fecal indicator bacteria guideline values to ensure minimum adverse environmental impact [25]. However, there are currently no guidelines to monitor antibiotic resistant $E$. coli in reuse water. The results of our study provide baseline information on the occurrence of these antibiotic-resistant indicator bacteria.

Multiple disinfection methods (UV followed by chlorination) applied during the reclaimed water production significantly decreased the number of E. coli. In an earlier study, [26] estimated 3.9 log removal of fecal indicator bacteria in a WWTP utilized for reuse purposes; approximately 2 logs lower than our findings. This may be a result of different treatment methods among WWTPs. Earlier studies showed that chlorine-related disinfection by-products might potentially induce antibiotic resistance [27], and UV may not entirely remove antibiotics or antibiotic resistant genes from the effluent [28]. In addition, [29] showed that rapid sand filtration used for wastewater treatment failed to remove E. coli cells. The USEPA states in the guidelines of water reuse that the reclaimed water programs vary with the intensity of treatment based on the anticipated human exposure to the effluent [30]. The variability in resistance is not only limited to the treatment type, and environmental conditions may have a significant impact on the occurrence of antibiotic-resistant $E$. coli even within the same plant. Our study showed that the antibiotic-resistant $E$. coli concentrations were high at the effluent when there was rain prior to the sampling event. Precipitation events are often a burden on the treatment efficacy. Earlier studies showed an association between heavy rainfall and pathogen removal [31]. A metagenomics study in wastewater treatment plants also showed that the diversity in the microbial community significantly increased after rainfall events [32], suggesting poor disinfection due to increased flow and short retention time. Further research is needed with a study designed specifically to assess the impact of rain on the removal efficiency of antibiotic-resistant bacteria.

Another important finding was that one in every five E. coli isolated from the WWTP had multidrug resistance. Similarly, [33] found that E. coli O157:H7 plasmids were resistant to seven different antibiotics including ampicillin, ciprofloxacin, and tetracycline. It is well known that E. coli can survive long-term and proliferate in the environment [34], and that the long-term persistence of antibiotic-resistant $E$. coli can cause potential public health outcomes upon exposure. Therefore, the ecology of E. coli-in particular, persistence and seasonality-plays a significant role in the health risks $[35,36]$. Investigating the culturable fraction of antibiotic-resistant bacteria through WWTP stages in our study provided information that can further be used to assess health risk upon exposure. A majority of the studies on the antibiotic resistance from WWTP have investigated antibiotic resistance genes, which provide vast knowledge on the horizontal gene transport and fate of these genes during treatment. However, these genes may exist in the wastewater as naked DNA. In addition, antibiotic-resistant genes can be naturally found in the environment as these genes have been detected in pristine environments dating back thousands of years, before the antibiotic era $[14,37,38]$. These genes may also persist in the environment longer than the cells, which may cause an overestimation of the health risk. Earlier studies showed that $E$. coli genes decayed slower than cultivated E. coli in water ( $\mathrm{T}_{99}=5.65$ days and 2.02 days, respectively) [39-41]. Therefore, investigating the culturable fraction of antibiotic resistance can help to fill some of these knowledge gaps to estimate health risk.

The E. coli that are resistant to certain antibiotics which have been used for a long time in medicine could still be detected at the effluent even after multiple disinfection steps. For example, approximately $50 \%$ of the E. coli entering the WWTP were resistant to ampicillin, and the percentage increased to $63 \%$ at the effluent before leaving the plant after disinfecting with both UV and chlorine. Moreover, three out of four isolates of E. coli with multidrug resistance had minimum inhibition 
concentrations that were above the detection limits. These results suggest that the total E. coli community may have serotypes that are resistant to antibiotics and disinfection at the same time. Similar to our findings, [42] suggested that the disinfection byproducts promoted the evolution of resistant E. coli strains. Similarly, [43] showed that the dose applied for UV disinfection can create a selective environment for antibiotic resistant $E$. coli to survive better than other serotypes within the population. These findings suggest that better treatment processes are needed to take over old technologies to mitigate antibiotic resistance in the environment. Studies have shown that membrane bioreactor systems are capable of achieving better removal of microorganisms than conventional activated sludge systems [44]. Alternatively, tertiary treatment with filtration followed by disinfection was also reported to be effective in antibiotic resistance removal [45]. Approaches such as these relatively new technologies may reduce the antibiotic-resistant bacteria load entering aquatic environment.

\section{Conclusions}

The findings of this study show that using conventional methods of wastewater treatment to produce reclaimed water may pose challenges to removing antibiotic-resistant bacteria. Factors impacting the treatment efficacy such as the microbial community composition entering and leaving the plant, physicochemical factors impacting treatment, and extreme weather events that can adversely affect the flow and overall plant capacity need to be addressed while tackling the contribution of WWTP to antibiotic resistance in the environment. Our results show that multiple disinfection methods such as UV and chlorination may remove fecal indicator bacteria to acceptable levels for reuse, but the remaining cells in the effluent exhibit multidrug resistance phenotypes. The presence of these strains in the effluent needs to be considered while developing new regulations for water reuse. Further research is required in order to evaluate the health risks of using reclaimed water harboring antibiotic-resistant bacteria for drinking, agricultural, and recreational purposes.

Author Contributions: A.A. designed the study and wrote the manuscript; Z.C. contributed to sample collection; Z.C. and O.O. performed the laboratory analysis; Z.C. and A.B. analyzed the data.

Funding: This research was funded by Georgia Southern University Office of Research and Development.

Conflicts of Interest: The authors declare no conflict of interest.

\section{References}

1. Davies, J.; Davies, D. Origins and evolution of antibiotic resistance. Microbiol. Mol. Biol. Rev. 2010, 74, 417-433. [CrossRef] [PubMed]

2. Stoll, C.; Sidhu, J.P.S.; Tiehm, A.; Toze, S. Prevalence of clinically relevant antibiotic resistance genes in surface water samples collected from Germany and Australia. Environ. Sci. Technol. 2012, 46, 9716-9726. [CrossRef] [PubMed]

3. Burch, T.R.; Sadowsky, M.J.; LaPara, T.M. Fate of antibiotic resistance genes and class 1 integrons in soil microcosms following the application of treated residual municipal wastewater solids. Environ. Sci. Technol. 2014, 48, 5620-5627. [CrossRef] [PubMed]

4. Ben, W.; Wang, J.; Cao, R.; Yang, M.; Zhang, Y.; Qiang, Z. Distribution of antibiotic resistance in the effluents of ten municipal wastewater treatment plants in China and the effect of treatment processes. Chemosphere 2017, 172, 392-398. [CrossRef] [PubMed]

5. Li, X.; Watanabe, N.; Xiao, C.; Harter, T.; McCowan, B.; Liu, Y.; Atwill, E.R. Antibiotic-resistant E. coli in surface water and groundwater in dairy operations in Northern California. Environ. Monit. Assess. 2014, 186, 1253-1260. [CrossRef] [PubMed]

6. Carnelli, A.; Mauri, F.; Demarta, A. Characterization of genetic determinants involved in antibiotic resistance in Aeromonas spp. and fecal coliforms isolated from different aquatic environments. Res. Microbiol. 2017, 168, 461-471. [CrossRef] [PubMed] 
7. Port, J.A.; Cullen, A.C.; Wallace, J.C.; Smith, M.N.; Faustman, E.M. Metagenomic frameworks for monitoring antibiotic resistance in aquatic environments. Environ. Health Perspect. 2014, 122, 222-228. [CrossRef] [PubMed]

8. Manaia, C.M.; Macedo, G.; Fatta-Kassinos, D.; Nunes, O.C. Antibiotic resistance in urban aquatic environments: Can it be controlled? Appl. Microbiol. Biotechnol. 2016, 100, 1543-1557. [CrossRef] [PubMed]

9. Zhang, S.; Han, B.; Gu, J.; Wang, C.; Wang, P.; Ma, Y.; Cao, J.; He, Z. Fate of antibiotic resistant cultivable heterotrophic bacteria and antibiotic resistance genes in wastewater treatment processes. Chemosphere 2015, 135, 138-145. [CrossRef] [PubMed]

10. Frey, S.K.; Topp, E.; Khan, I.U.H.; Ball, B.R.; Edwards, M.; Gottschall, N.; Sunohara, M.; Lapen, D.R. Quantitative Campylobacter spp., antibiotic resistance genes, and veterinary antibiotics in surface and ground water following manure application: Influence of tile drainage control. Sci. Total Environ. 2015, 532, 138-153. [CrossRef] [PubMed]

11. Wang, F.-H.; Qiao, M.; Lv, Z.-E.; Guo, G.-X.; Jia, Y.; Su, Y.-H.; Zhu, Y.-G. Impact of reclaimed water irrigation on antibiotic resistance in public parks, Beijing, China. Environ. Pollut. 2014, 184, 247-253. [CrossRef] [PubMed]

12. Blaustein, R.A.; Shelton, D.R.; Van Kessel, J.A.; Karns, J.S.; Stocker, M.D.; Pachepsky, Y.A. Irrigation waters and pipe-based biofilms as sources for antibiotic-resistant bacteria. Environ. Monit. Assess. 2016, 188, 56. [CrossRef] [PubMed]

13. World Health Organization. Antimicrobial Resistance: An emerging Water, Sanitation and Hygiene Issue Briefing Note; WHO/FWC/WSH/14.07; World Health Organization: Geneva, Switzerland, 2014. [CrossRef]

14. Xu, J.; Chen, W.; Wu, L.; Green, R.; Chang, A.C. Leachability of some emerging contaminants in reclaimed municipal wastewater-irrigated turf grass fields. Environ. Toxicol. Chem. 2009, 28, 1842-1850. [CrossRef] [PubMed]

15. United States Environmental Protection Agency. Method 1604: Total Coliforms and Escherichia coli in Water by Membrane Filtration Using a Simultaneous Detection Technique (MI Medium); Standard Methods, EPA-821-R-02-024; United States Environmental Protection Agency: Washington, DC, USA, 2002.

16. Brenner, K.P.; Rankin, C.C.; Roybal, Y.R.; Stelma, G.N.; Scarpino, P.V; Dufour, A.P. New medium for the simultaneous detection of total coliforms and Escherichia coli in water. Appl. Environ. Microbiol. 1993, 59, 3534-3544. [PubMed]

17. Clinical and Laboratory Standards Institute. Performance Standards for Antimicrobial Susceptibility Testing, 27th ed.; CLSI Supplement M100; Clinical and Laboratory Standards Institute: Wayne, PA, USA, 2017.

18. Watkinson, A.J.; Micalizzi, G.R.; Bates, J.R.; Costanzo, S.D. Novel method for rapid assessment of antibiotic resistance in Escherichia coli isolates from environmental waters by use of a modified chromogenic agar. Appl. Environ. Microbiol. 2007, 73, 2224-2229. [CrossRef] [PubMed]

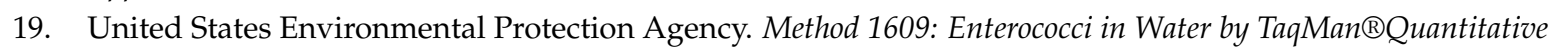
Polymerase Chain Reaction ( $(P C R)$ with Internal Amplification Control (IAC) Assay; Standard Methods, EPA-820-R-15-099; U.S. Environmental Protection Agency: Washington, DC, USA, 2015.

20. Chern, E.C.; Siefring, S.; Paar, J.; Doolittle, M.; Haugland, R.A. Comparison of quantitative PCR assays for Escherichia coli targeting ribosomal RNA and single copy genes. Lett. Appl. Microbiol. 2011, 52, $298-306$. [CrossRef] [PubMed]

21. Roe, M.T.; Vega, E.; Pillai, S.D. Antimicrobial resistance markers of Class 1 and Class 2 Integron-bearing Escherichia coli from irrigation water and sediments. Emerg. Infect. Dis. 2003, 9, 822-826. [CrossRef] [PubMed]

22. Vital, P.G.; Zara, E.S.; Paraoan, C.E.M.; Dimasupil, M.A.Z.; Abello, J.J.M.; Santos, I.T.G.; Rivera, W.L. Antibiotic resistance and extended-spectrum beta-lactamase production of Escherichia coli isolated from irrigation waters in selected urban farms in metro Manila, Philippines. Water 2018, 10, 548. [CrossRef]

23. Aijuka, M.; Charimba, G.; Hugo, C.J.; Buys, E.M. Characterization of bacterial pathogens in rural and urban irrigation water. J. Water Health 2015, 13, 103-117. [CrossRef] [PubMed]

24. Ishii, S.; Sadowsky, M.J. Escherichia coli in the environment: Implications for water quality and human health. Microbes Environ. 2008, 23, 101-108. [CrossRef] [PubMed]

25. Smith, J.E.; Perdek, J.M. Assessment and management of watershed microbial contaminants. Crit. Rev. Environ. Sci. Technol. 2004, 34, 109-139. [CrossRef] 
26. Al-Jassim, N.; Ansari, M.I.; Harb, M.; Hong, P.Y. Removal of bacterial contaminants and antibiotic resistance genes by conventional wastewater treatment processes in Saudi Arabia: Is the treated wastewater safe to reuse for agricultural irrigation? Water Res. 2015, 73, 277-290. [CrossRef] [PubMed]

27. Kim, I.; Yamashita, N.; Tanaka, H. Performance of UV and $\mathrm{UV} / \mathrm{H}_{2} \mathrm{O}_{2}$ processes for the removal of pharmaceuticals detected in secondary effluent of a sewage treatment plant in Japan. J. Hazard. Mater. 2009, 166, 1134-1140. [CrossRef] [PubMed]

28. Xi, C.; Zhang, Y.; Marrs, C.F.; Ye, W.; Simon, C.; Foxman, B.; Nriagu, J. Prevalence of antibiotic resistance in drinking water treatment and distribution systems. Appl. Environ. Microbiol. 2009, 75, 5714-5718. [CrossRef] [PubMed]

29. Srinivasan, S.; Aslan, A.; Xagoraraki, I.; Alocilja, E.; Rose, J.B. Escherichia coli, Enterococci, and Bacteroides thetaiotaomicron qPCR signals through wastewater and septage treatment. Water Res. 2011, 45, 2561-2572. [CrossRef] [PubMed]

30. United States Environmental Protection Agency. Guidelines for Water Reuse; EPA/600/R-12/61; U.S. Environmental Protection Agency: Washington, DC, USA, 2012.

31. Carducci, A.; Verani, M. Effects of bacterial, chemical, physical and meteorological variables on virus removal by a wastewater treatment plant. Food Environ. Virol. 2013, 5, 69-76. [CrossRef] [PubMed]

32. McLellan, S.L.; Huse, S.M.; Mueller-Spitz, S.R.; Andreishcheva, E.N.; Sogin, M.L. Diversity and population structure of sewage-derived microorganisms in wastewater treatment plant influent. Environ. Microbiol. 2010, 12, 378-392. [CrossRef] [PubMed]

33. Chigor, V.N.; Umoh, V.J.; Smith, S.I.; Igbinosa, E.O.; Okoh, A.I. Multidrug resistance and plasmid patterns of Escherichia coli $\mathrm{O} 157$ and other E. coli isolated from diarrhoeal stools and surface waters from some selected sources in Zaria, Nigeria. Int. J. Environ. Res. Public Health 2010, 7, 3831-3841. [CrossRef] [PubMed]

34. Winfiel, M.D.; Groisman, E.A. Role of nonhost enviroments in the lifestyles of Salmonella and E. coli. Appl. Environ. Microbiol. 2003, 69, 3687-3694. [CrossRef]

35. McLain, J.E.T.; Williams, C.F. Assessing environmental impacts of treated wastewater through monitoring of fecal indicator bacteria and salinity in irrigated soils. Environ. Monit. Assess. 2012, 184, 1559-1572. [CrossRef] [PubMed]

36. Jiang, Y.; Xu, C.; Wu, X.; Chen, Y.; Han, W.; Gin, K.Y.H.; He, Y. Occurrence, seasonal variation and risk assessment of antibiotics in Qingcaosha reservoir. Water 2018, 10, 115. [CrossRef]

37. Bhullar, K.; Waglechner, N.; Pawlowski, A.; Koteva, K.; Banks, E.D.; Johnston, M.D.; Barton, H.A.; Wright, G.D. Antibiotic resistance is prevalent in an isolated cave microbiome. PLoS ONE 2012, 7. [CrossRef] [PubMed]

38. Dcosta, V.M.; King, C.E.; Kalan, L.; Morar, M.; Sung, W.W.L.; Schwarz, C.; Froese, D.; Zazula, G.; Calmels, F.; Debruyne, R.; et al. Antibiotic resistance is ancient. Nature 2011, 477, 457-461. [CrossRef] [PubMed]

39. Jin, G.; Englande, A.J.; Bradford, H.; Englande, A.J. Comparison of E. coli, Enterococci, and fecal coliform as indicators for brackish water quality assessment. Water Environ. Res. 2004, 76, 245-255. [CrossRef] [PubMed]

40. Dick, L.K.; Stelzer, E.A; Bertke, E.E.; Fong, D.L.; Stoeckel, D.M. Relative decay of Bacteroidales microbial source tracking markers and cultivated Escherichia coli in freshwater microcosms. Appl. Environ. Microbiol. 2010, 76, 3255-3262. [CrossRef] [PubMed]

41. Martinez, J.L. Environmental pollution by antibiotics and by antibiotic resistance determinants. Environ. Pollut. 2009, 157, 2893-2902. [CrossRef] [PubMed]

42. Li, D.; Zeng, S.; He, M.; Gu, A.Z. Water disinfection byproducts induce antibiotic resistance-role of environmental pollutants in resistance phenomena. Environ. Sci. Technol. 2016, 50, 3193-3201. [CrossRef] [PubMed]

43. Zhang, C.-M.; Xu, L.-M.; Wang, X.-C.; Zhuang, K.; Liu, Q.-Q. Effects of ultraviolet disinfection on antibiotic-resistant Escherichia coli from wastewater: Inactivation, antibiotic resistance profiles and antibiotic resistance genes. J. Appl. Microbiol. 2017, 123, 295-306. [CrossRef] [PubMed] 
44. Zhang, K.; Farahbakhsh, K. Removal of native coliphages and coliform bacteria from municipal wastewater by various wastewater treatment processes: Implications to water reuse. Water Res. 2007, 41, 2816-2824. [CrossRef] [PubMed]

45. Quach-Cu, J.; Herrera-Lynch, B.; Marciniak, C.; Adams, S.; Simmerman, A.; Reinke, R.A. The effect of primary, secondary, and tertiary wastewater treatment processes on antibiotic resistance gene (ARG) concentrations in solid and dissolved wastewater fractions. Water 2018, 10, 37. [CrossRef] 